\title{
IMPORTANCE OF OXYGEN REGIME INDICATORS - CASE STUDY OF THE NIŠAVA RIVER IN SERBIA
}

\author{
UDC 556.5:546.21(497.11)
}

\section{Žarko Vranjanac, Dejan Vasović}

University of Niš, Faculty of Occupational Safety in Niš, Niš, Serbia

\begin{abstract}
From a global perspective, there is currently an ever-increasing problem of natural water resource pollution and daily decrease of available amounts of potable water. In addition to the definition of their ecological status, the existing problems of polluted water systems also require that parameters of the oxygen regime should be determined. The importance of monitoring the indicators of oxygen regime in rivers is aimed at achieving sustainable water management and preserving environmental quality. Oxygen regime in the Nišava river ecosystem is monitored based on specific physico-chemical indicators: biological oxygen demand (BOD), chemical oxygen demand (COD), total organic carbon (TOC), dissolved oxygen and oxygen saturation. The aim of this paper is to demonstrate the significance of oxygen regime indicators by monitoring their concentrations at measuring stations along the Nišava, which can help assess the quality of the given aquatic ecosystem. The paper relies on the Results of Surface and Ground Water Quality Testing by the Environmental Protection Agency, Ministry of Agriculture and Environmental Protection of the Republic of Serbia for two measuring stations along the Nišava in 2013. Mean annual concentrations of oxygen regime indicators for 2013 are $B O D=2.6 \mathrm{mg} / \mathrm{L}$ and $C O D=4.3 \mathrm{mg} / \mathrm{L}$, which indicates that the value of their respective ratio is 0.6 , which is important for oxygen regime. A comparative analysis performed by the water supply PUC "Naissus", based on the values of these environmental indicators, also confirmed that water quality in the Nišava corresponds to Class II surface water. Therefore, this paper highlights the importance of monitoring oxygen regime indicators of the Nišava River for the purpose of sustainable water management and environmental quality preservation.
\end{abstract}

Key words: the Nišava River, indicators of oxygen regime, case study

\section{INTRODUCTION}

Monitoring of surface water quality involves observation, supervision, and monitoring of the state of surface waters. The monitoring is conducted according to specified

Received March 22, 2017 / Accepted October 17, 2017

Corresponding author: Žarko Vranjanac

Faculty of Occupational Safety, Čarnojevića 10a, 18000 Niš, Serbia

E-mail: zarko.vranjanac@znrfak.ni.ac.rs 
parameters, i.e. indicators of surface water quality. In Serbia, the monitoring of surface water quality is conducted by the Serbian Environmental Protection Agency and it is included in the national monitoring system under the purview of the Serbian Government. Surface water quality monitoring is conducted via measuring stations, which together form a monitoring network (Figure 1). A mandatory part of the monitoring is the announcement of the data obtained through continuous measurement of specific target parameters utilized for that purpose [2].

The Nišava is a part of the South Morava basin and it is its largest tributary. There are two measuring stations on the Nišava (Dimitrovgrad and Niš), which are used to monitor the physico-chemical parameters on the basis of which the oxygen regime of the Nišava can be determined. Dimitrovgrad measuring station includes the course of the Nišava upstream of the bridge near the village of Dolac all the way to the country's border. Niš measuring station includes the course of the Nišava from its confluence into the South Morava to the confluence of the Studena River [5].

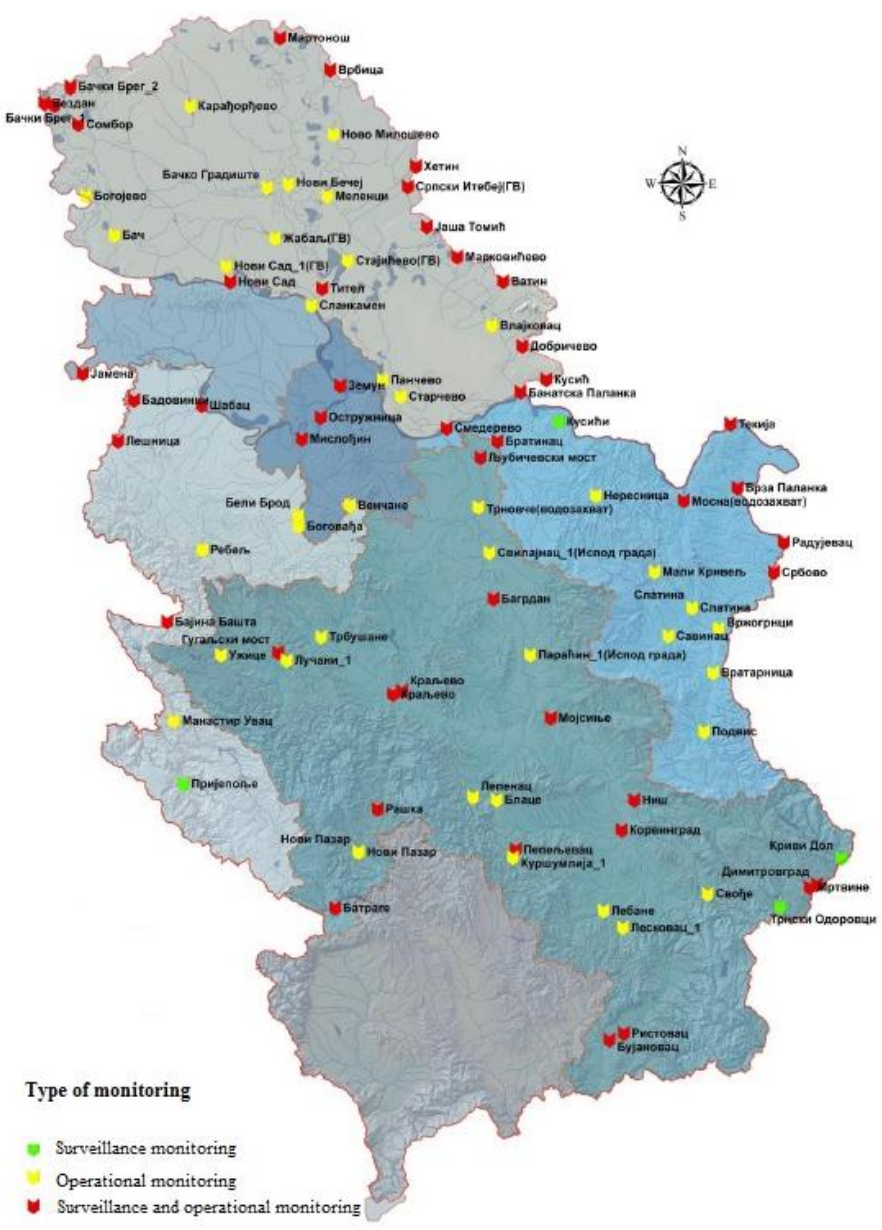

Fig. 1 Network of watercourse measuring stations in Serbia 


\section{THE EXPERIMENTAL}

The methods for determining watercourse and surface water oxygen regime used in this paper rely on the physico-chemical indicators [9] and basic legislation regulating this field: Council Directive 74/440 EEC concerning the quality required of surface waters intended for the abstraction of drinking water in Member States [1] and the Regulation on the parameters of ecological and chemical status of surface water and the parameters of chemical and quantitative status of groundwater ("Official Gazette of the Republic of Serbia", No. 74/2011) [7]. Based on the Regulation on determining the water bodies of surface water and groundwater ("Official Gazette of the Republic of Serbia", No. 50/2012), all surface water bodies are classified into six types, according to which the Nišava is the great river, the dominance of the middle sediment, except for river areas of the Pannonian Plain [4].

Oxygen regime in the Nišava ecosystem is monitored according to the specified physicochemical indicators: biological oxygen demand (BOD), chemical oxygen demand (COD), total organic carbon (TOC), dissolved oxygen, and oxygen saturation [6].

\section{RESULTS AND DISCUSSION}

According to the Regulation on the parameters of ecological and chemical status of surface water and the parameters of chemical and quantitative status of groundwater, ecological status of rivers in Serbia is classified as excellent (I), good (II), and moderate (III). Since the Nišava water course is categorized as type II [4], Table 1 presents the thresholds between ecological status classes for this type of water body [5].

Table 1 Thresholds between ecological status classes for type 2 water body

\begin{tabular}{|c|c|c|c|c|c|}
\hline \multirow[t]{2}{*}{ Parameter } & \multirow[t]{3}{*}{ Unit } & \multicolumn{4}{|c|}{ Thresholds between ecological status classes } \\
\hline & & I-II & II-III & III-IV & IV-V \\
\hline $\mathrm{pH}$ value & & $6.5-8.5$ & $6.5-8.5$ & $6.5-8.5$ & $<6.5 ;>8.5$ \\
\hline Dissolved oxygen & $\mathrm{mg} \mathrm{l}^{-1}$ & 8.5 & 7.0 & 5.0 & 4.0 \\
\hline $\mathrm{BOD}_{5}$ & $\mathrm{mg} \mathrm{l}^{-1}$ & 1.8 & 4.5 & 6.0 & 20.0 \\
\hline Total organic carbon (TOC) & $\mathrm{mg} \mathrm{l}^{-1}$ & 2.0 & 5.0 & 7.0 & 23.0 \\
\hline Ammonium ion $\left(\mathrm{NH}_{4}-\mathrm{N}\right)$ & $\mathrm{mg} \mathrm{l}^{-1}$ & 0.05 & 0.1 & 0.8 & 1.0 \\
\hline Nitrates $\left(\mathrm{NO}_{3}-\mathrm{N}\right)$ & $\mathrm{mg} \mathrm{l}^{-1}$ & 1.50 & 3.00 & 6.00 & 15.00 \\
\hline Orthophosphates $\left(\mathrm{PO}_{4}-\mathrm{P}\right)$ & $\mathrm{mg} \mathrm{l}^{-1}$ & 0.02 & 0.1 & 0.2 & 0.5 \\
\hline Total dissolved phosphorus (P) & $\mathrm{mg} \mathrm{l}^{-1}$ & 0.05 & 0.2 & 0.4 & 1.0 \\
\hline Chlorides & $\mathrm{mg} \mathrm{l}^{-1}$ & 50 & 100 & - & - \\
\hline
\end{tabular}

The results of tests for the quality of surface and groundwater for 2013, conducted by the Serbian Ministry of Agriculture and Environmental Protection, include the indicators on whose basis the oxygen regime for the Nišava is determined [3]. Table 2 shows the calculated mean annual concentrations of indicators measured at measuring stations Dimitrovgrad and Niš in 2013, respectively. 
Table 2 Mean values of indicators for measuring stations Dimitrovgrad and Niš, 2013

\begin{tabular}{lccc}
\hline Indicator & Unit & $\begin{array}{c}\text { Mean value at meas. } \\
\text { stat. Dimitrovgrad }\end{array}$ & $\begin{array}{c}\text { Mean value at } \\
\text { meas. stat. Niš }\end{array}$ \\
\hline Chemical oxygen demand (COD) & $\mathrm{mg} \mathrm{l}^{-1}$ & 2.7 & 6.0 \\
Dissolved oxygen & $\mathrm{mg} \mathrm{l}^{-1}$ & 10.5 & 6.7 \\
Biological oxygen demand (BOD) & $\mathrm{mg} \mathrm{l}^{-1}$ & 2.0 & 3.2 \\
Total organic carbon (TOC) & $\mathrm{mg} \mathrm{l}^{-1}$ & 3.5 & 6.5 \\
Oxygen saturation & $\%$ & 99.1 & 64.6 \\
\hline
\end{tabular}

Based on these data, it can be concluded that the mean values of parameters that affect the oxygen regime of the Nišava differ considerably between the measuring stations. Chemical oxygen demand (COD) value is significantly higher at the Niš measuring station, whereas dissolved oxygen level is higher at the Dimitrovgrad measuring station. Biological oxygen demand (BOD) [8], as well as total organic carbon (TOC) concentrations, are higher at the Niš measuring station. Percentage of oxygen saturation is higher at the Dimitrovgrad measuring station. In addition to the aforementioned indicators, another important indicator of the oxygen regime is the BOD/COD ratio. This ratio is higher at the Dimitrovgrad measuring station (0.74) than at the Niš station (0.53). This is due to the size of the water course area, as well as due to specific orographic properties, which cannot be directly associated with the impact of pollution on water quality. The value of this ratio that is the closest to the recommended value was measured at the Niš measuring station.

Table 3 shows the calculated mean concentrations of oxygen regime indicators for the Nišava water course.

Table 3 Oxygen regime indicators for the Nišava water course, 2013

\begin{tabular}{lcc}
\hline Indicator & Units & $\begin{array}{c}\text { Mean value } \\
\text { for the Nišava }\end{array}$ \\
\hline Chemical oxygen demand (COD) & $\mathrm{mg} \mathrm{l}^{-1}$ & 4.3 \\
Dissolved oxygen & $\mathrm{mg} \mathrm{l}^{-1}$ & 8.6 \\
Biological oxygen demand (BOD) & $\mathrm{mg} \mathrm{l}^{-1}$ & 2.6 \\
Total organic carbon (TOC) & $\mathrm{mg} \mathrm{l}^{-1}$ & 5.0 \\
Oxygen saturation & $\%$ & 81.8 \\
BOD/COD & - & 0.6 \\
\hline
\end{tabular}

Comparison of mean values for the Nišava water course with the values from the Regulation on limit values for pollutants in surface and groundwater and sediments and deadlines for their achievement (Official Gazette of the Republic of Serbia, No. 50/2012) [4], as well as with the BOD/COD ratio, revealed that the impact on oxygen regime occurred due to increased concentrations of specific indicators. Comparison of oxygen regime indicators can be made directly from Figure 2, for Dimitrovgrad and Niš measuring stations and the Nišava water course, in order to obtain a clearer picture of the importance of oxygen regime indicators [3]. 


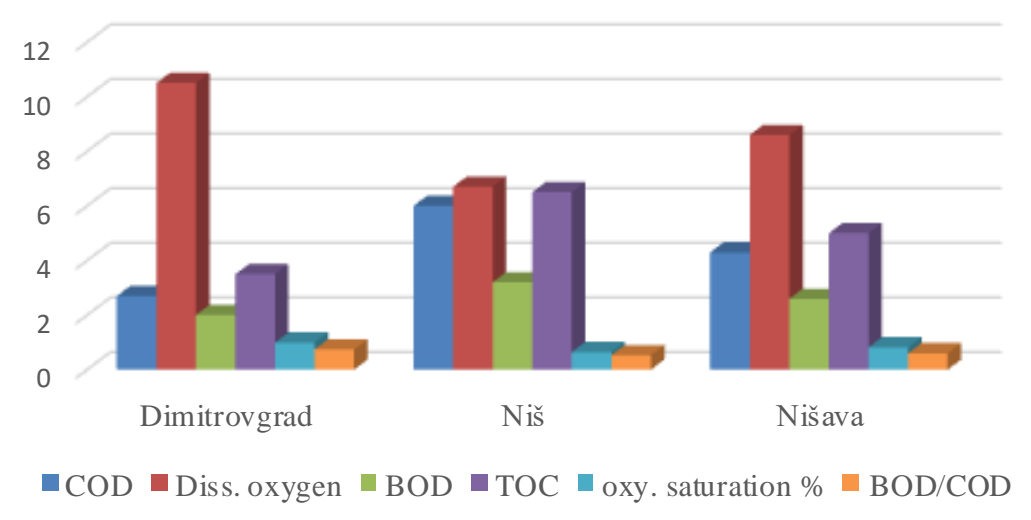

Fig. 2 Indicators that affect the oxygen regime of the Nišava in $\mathrm{mg} \mathrm{l}^{-1}, 2013$

\section{CONCLUSION}

After comparing mean indicator values with the values from Table 1, which refers to the limit values of pollutants in surface water, Regulation on limit values for pollutants in surface and ground waters and sediments and deadlines for their achievement (Official Gazette of the Republic of Serbia, No. 50/2012), it can be concluded that the Nišava water course belongs to Class II [5], taking into account its ecological status. Paragraph 5 of Article 5 of the Regulation on the parameters of ecological and chemical status of surface water and the parameters of chemical and quantitative status of groundwater ("Official Gazette of the Republic of Serbia", No. 74/2011) strictly states that "If one or more parameters of ecological status exceed the limits of good status, ecological status of surface waters can be mostly classified as moderate" [7].

Year after year, the indicators of surface water courses quality are becoming increasingly favorable [6]. This is not a result of an ideal system of monitoring and surface water protection, but rather of the fact that Serbian industry and manufacture operate at a reduced capacity. In the City of Nišs, the biggest industrial giants have been closed down, which is the reason for the absence of heavy polluters of the Nišava River. This was also confirmed by the results of tests performed by the PUC "Naissus", Niš, to which we were privy after our visit to their laboratory.

From the water supply perspective, the Nišava water course belongs to the A2 category of water courses (Annex 1, Council Directive 74/440 EEC concerning the quality required of surface waters intended for the abstraction of drinking water in Member States) appropriate water treatment methods are recommended [1]. Using methodological recommendations, methods for treating potable water intended for water supply can be realized successfully, which is indicated by the final Nišava BOD/COD ratio of 0.6.

This paper highlighted the importance of monitoring the oxygen regime indicators for the Nišava river water course, even though there are currently no heavy polluters or negative impacts on water quality. The monitoring of oxygen regime indicators for the Nišava is primarily important because it provides a clearer picture on the state of surface water quality, on the basis of which specific oxygen regime indicators relevant for the monitoring can be identified, which is ultimately aimed towards achieving sustainable water management and preserving environmental quality. 
Acknowledgement: The paper is a part of the research conducted within the projects No. III43014, funded by the Serbian Ministry of Education, Science and Technological Development.

\section{REFERENCES}

1. Council Directive 75/440/EEC of 16 June 1979 concerning the quality required of surface water intended for the abstraction of drinking water in the Member States: Official Journal L 194, 25 July 1975, p. 26.

2. Directive 2000/60/EC of the European Parliament and of the Council establishing a framework for Community action in the field of water policy, EU Water Framework Directive. (http://ec.europa.eu/environment/water/waterframework/index_en.htm.)

3. Ministry of Agriculture and Environmental Protection, Serbian Environmental Protection Agency, Annual Report: The results of the quality of surface and groundwater for 2013, Belgrade 2014.

4. Regulation on determining the water bodies of surface water and groundwater "Official Gazette of the RS", No. 50/2012.

5. Regulation on limit values for pollutants in surface and groundwater and sediments and deadlines for their achievement, "Official Gazette of the RS", no. 50/2012.

6. Regulation on the national list of environmental indicators, "Official Gazette of the RS", No. 37/2011.

7. Regulation on the parameters of the ecological and chemical status of surface water and the parameters of the chemical and quantitative status of groundwater, "Official Gazette of the RS", No. 74/2011.

8. Takić Lj., Mladenović-Ranisavljević I., Stamenković I., Živković N., Environmental assessment as a function of the BOD-5 parameter value, $46^{\text {th }}$ International October Conference on Mining and Metallurgy, pp. 473-476, 2014., Bor, Serbia.

9. Takić Lj., Vasović D., Živković N., Indicators of oxygen demand in the ecosystem of the Danube in Serbia, Facta Universitatis Series: Working and Living Environmental Protection Vol.13, No 1, 2016, pp. 35-39.

\section{ZNAČAJ INDIKATORA KISEONIČNOG REŽIMA - STUDIJA SLUČAJA REKA NIŠAVA U SRBIJI}

Globalno posmatrano, danas je sve prisutniji problem zagađenja prirodnih resursa vode $i$ svakodnevno smanjivanje raspoloživih količina higijenski ispravne vode za piće. Postojeći problemi zagađenja vodnih sistema zahtevaju pored utvrđivanja ekološkog statusa kiseoničnog režima. Značaj praćenja indikatora kiseoničnog režima u rekama ima za cilj ostvarivanje održivog upravljanja vodama $i$ očuvanje kvaliteta životne sredine. Režim kiseonika u ekosistemu reke Nišave prati se na osnovu određenih fizičko-hemijskih indikatora. Ti indikatori su: biološka potrošnja kiseonika (BPK), hemijska potrošnja kiseonika (HPK), ukupni organski ugljenik (TOC), rastvoreni kiseonik i stepen zasićenosti kiseonikom. Cilj rada je da se ukaže na značaj indikatora kiseoničnog režima, praćenjem vrednosti njihove koncentracije na mernim stanicama duž toka reke Nišave, čime se može oceniti kvalitet datog akvatičnog ekosistema. U radu su korišćeni Rezultati ispitivanja kvaliteta površinskih i podzemnih voda, Agencije za zaštitu životne sredine, Ministarstva poljoprivrede i zaštite životne sredine Republike Srbije za dve merne stanice na reci Nišavi u Srbiji za 2013. godinu. Srednje godišnje koncentracije vrednosti indikatora kiseoničnog režima, izračunate za 2013. godinu, su BPK $=2.6 \mathrm{mg} / \mathrm{L}$ i $\mathrm{HPK}=4.3 \mathrm{mg} / \mathrm{L}$, što ukazuje da je vrednost njihovog respektivnog odnosa 0.6, koji je značajan za kiseonični režim. Uporedna analiza, zasnovana na vrednostima ovih ekoloških pokazatelja u JKP "Naisus" Niš, takođe je pokazala da kvalitet vode u Nišavi odgovara II klasi kvaliteta površinskih voda. Zbog toga, ovaj rad ukazuje na značaj praćenja indikatora kiseoničnog režima vodotoka reke Nišave u cilju održivog upravljanja vodama i očuvanju kvaliteta životne sredine.

Ključne reči: reka Nišava, indikatori kiseoničnog režima, studija slučaja 